Kalpa Publications in Engineering
Volume 3, 2020, Pages 279-286
Proceedings of International Sym-
posium on Applied Science 2019

\title{
Effective Bone Regeneration Treatment Of Low-Level Laser
}

\author{
Hong Duyen Trinh Tran ${ }^{1 *}$, Minh Thai Tran ${ }^{1}$, Ngoc Dung Tran Thi ${ }^{1}$, Tam \\ Anh Pham Tran', To Ni Phan Van ${ }^{3}$ \\ ${ }^{1}$ University of Technology, VNU-HCM \\ ${ }^{2}$ Flinders University \\ ${ }^{3}$ Waseda University \\ tt_hd2005@hcmut.edu.vn
}

\begin{abstract}
This experimental study aimed to evaluate if the effect simultaneously wavelengths of $780 \mathrm{~nm}$ and $940 \mathrm{~nm}$ enhances bone regeneration of the broken bone. Experiments on pets: 14 dogs, were randomly divided into 2 groups: group I (low-level laser therapy) and group II (control). The results showed that dogs in group I had better bone regeneration and bone marrow formation than the control group. Then, we treated 25 patients with different fracture levels. They agreed to enjoy our method. After treatment, the fracture is no longer visible on X-ray film. The majority of patients after treatment only feel no pain or mild pain. This suggests that osteoblasts are positively affected when projected by low-level laser. It is very practical for the treatment of older patients because osteoblasts grow slowly than osteoclast.
\end{abstract}

\section{Introduction}

The musculoskeletal system forms the skeleton for the human body, which is responsible for lifting and mobilizing. Additionally, the skeletal system also has the function to create blood cells, fat reserves, mineral salts. The most common method of treating fractures is a cast, splint, or screw, etc. However, there are some inadequacies: for these treatments, after waiting for recovery, the patient has almost no movement at the site of the injury, so it is easy to lose sensation and muscle atrophy in these areas. There are cases of pain caused by patients refusing to exercise, leading to long-term pressure ulcers, even respiratory infections, blood vessel obstruction, decreased urination reflexes. Therefore, after being fixed at a broken position, the patient must be self-conscious, persistent, painproof, restore joint movement, maintain muscle strength, and the rate of bone healing will increase by exercise.[1] From these issues, we offer a new direction in our research that is the use of the two- 
wavelength effect simultaneously due to two types of semiconductor lasers working at 780nm and 940nm wavelengths, which impact the fracture site. We conduct experiments on dogs do to initially evaluate the efficiency of the two wavelengths effects simultaneously. This is an important step for us to treat different types of fractures for patients.

\section{The Equipment}

Low-level semiconductor laser equipment (Figure 1) is used in our research which is belong to the national research "B96.20.TĐ.06" of the Laser Technology laboratory - Ho Chi Minh City University of Technology. We use a low-level semiconductor laser device with a treatment head that is combined with two lasers working at $780 \mathrm{~nm}$ and $940 \mathrm{~nm}$ to create a two-wavelength effect simultaneously. The frequency of treatment is $50 \mathrm{~Hz}$. The level is $18 \mathrm{~mW}$. This effect is radiated treatment directly to the skin surface in the damaged area.

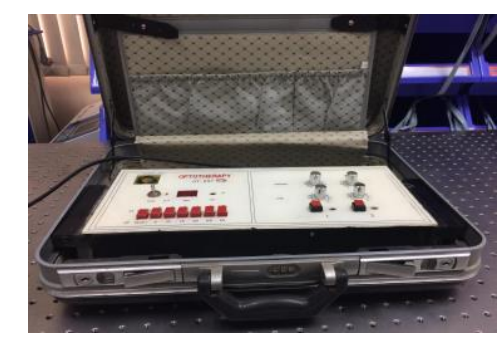

Figure 1: The low-level semiconductor laser equipment

\section{Model of Dog Fracture Treatment}

\subsection{Objective}

14 male and female dogs are randomly selected, about 2-3 years old, average weight from 6 - 10 $\mathrm{kg}$, healthy, flexible. They are raised under the same conditions (food, water, care) and are divided into two groups: Group I (laser): includes $10 \mathrm{dogs}$, group II (control): 04 dogs. The dog has a broken leg and a cast. Dogs in group I after cast, the broken leg is treated with a low-level laser. Dogs in the other group had broken legs for bone healing without treated with low-level lasers.

\subsection{Methods}

A course of treatment is 21 days. Each treatment is 30 minutes. The recognition of bone healing results of the two groups was assessed by the results of X-ray film at the times: after cast, after 14 days of treatment, after 21 days of treatment.

\subsection{Results}

After 14 days of the experiment (Figure 2), the bone marrow of the dog in group 1 is formed faster than that of the other group. We observe the fracture in group II at that time. At the end of the treatment, we recognized the formation of bone in group I become smoothy than that of the other group. Bone marrow has established in group II at the end of therapy. 


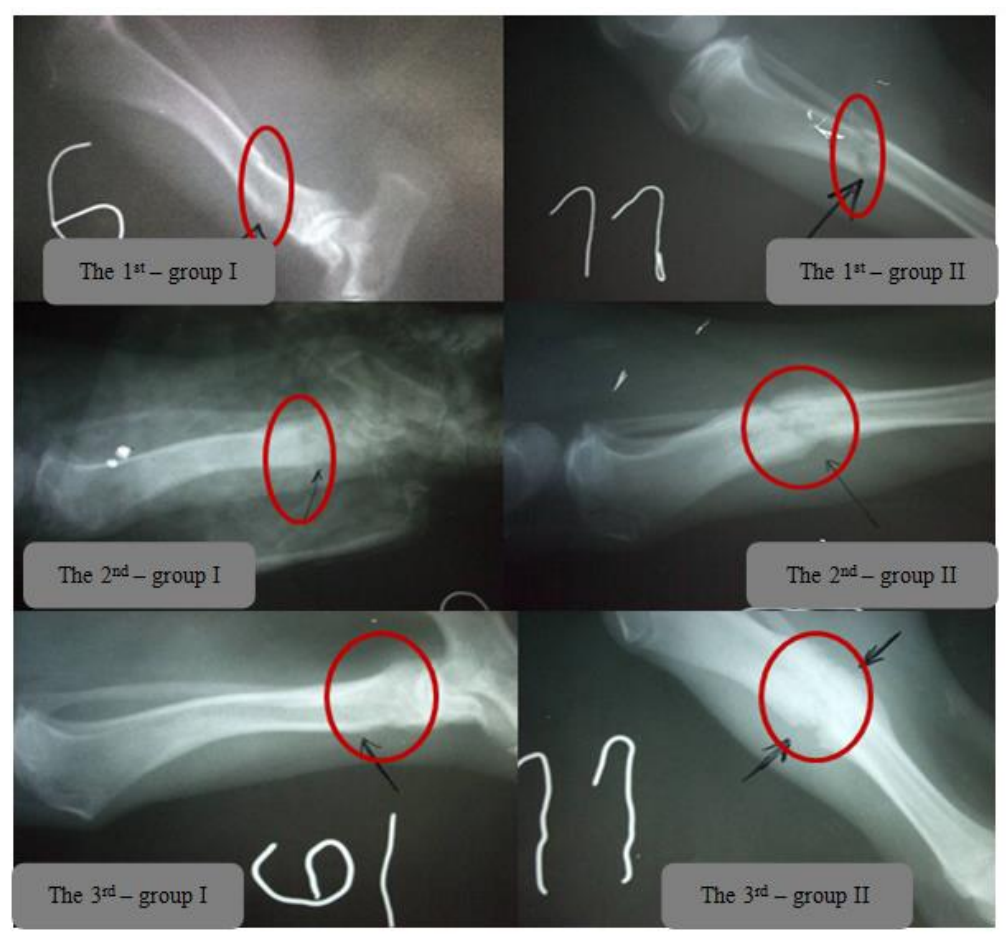

Figure 2: X-ray results at day 1 (time 1), day 14 (time 2) and day 21 (time 3) of dogs in group I and group II

\section{Clinical Treatment for Patient}

\subsection{Materials}

After the good results obtained in the treatment of experimentally in dogs, we combined with the doctor to perform the treatment for patients. Patients included 25 people (11 women and 14 men), they voluntarily participated in the research program. Our research method is clinical experiments.

13 patients under the age of 20 years. Because at this age, they exercise constantly, so the fracture due to injury is inevitable. 7 patients over 60 years old. At this age, the aging occurs rapidly, leading to bone weakness of these patients, brittle, so just a minor bump can also cause fractures. 5 patients in the age range $(21$ - 40) years, this is the working-age, so the fracture will greatly affect daily labor.

\subsection{Methods}

A course of treatment consists of 21 days. Depending on the degree of fracture that patients are treated with one, two or three-courses. (Figure 3). 


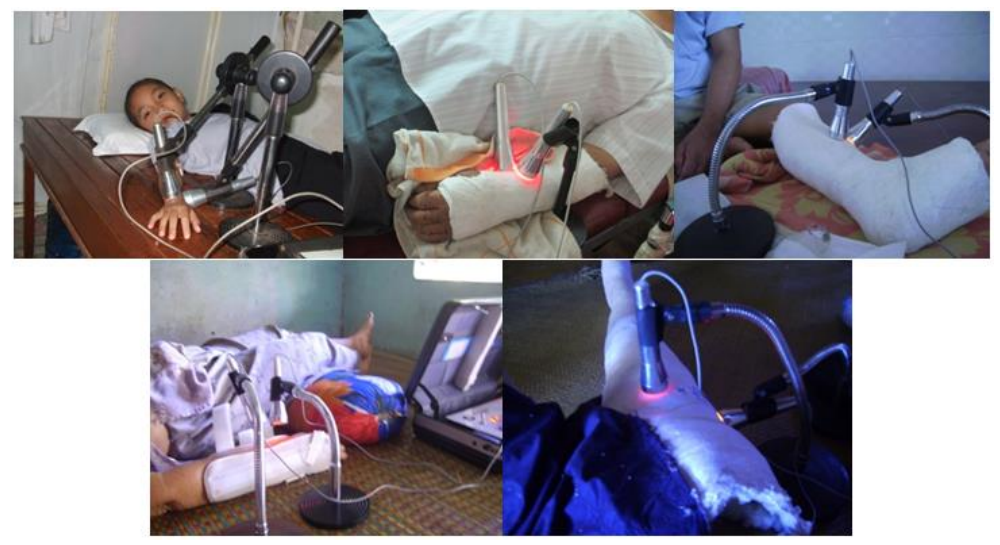

Figure 3: The difference position in fractures is treated by low-level laser

\subsection{Experiment}

The evaluation of treatment efficacy is based on the results of an X-ray of the patient before and after the end of treatment with low-level semiconductor lasers. Besides, the pain symptoms of the patient are examined and record by the doctor through the Mankoski pain scale [14] - This scale is used numbers and corresponding descriptions of pain so you can be sure that you and your healthcare provider understand one another (Table 1).

\begin{tabular}{lll}
\hline & Score & Description \\
\hline No pain & 0 & Pain-Free \\
\hline $\begin{array}{l}\text { Minor } \\
\text { Able to adapt to pain }\end{array}$ & 1 & Very minor annoyance - occasional minor twinges. \\
\cline { 2 - 3 } & 2 & Minor annoyance - occasional strong twinges. \\
\cline { 2 - 3 } $\begin{array}{l}\text { Moderate } \\
\text { Interferes with many activities }\end{array}$ & 5 & $\begin{array}{l}\text { Cannoying enough to be distracting. } \\
\text { distracting. }\end{array}$ \\
\cline { 2 - 3 } & 5 & $\begin{array}{l}\text { It can not be ignored for more than 30 minutes. } \\
\text { go to work and participate in social activities. }\end{array}$ \\
\hline $\begin{array}{l}\text { Serve } \\
\text { The patient is disabled and } \\
\text { unable to function } \\
\text { independently }\end{array}$ & 7 & $\begin{array}{l}\text { Makes it difficult to concentrate, interferes with sleep You } \\
\text { can still function with effort. }\end{array}$ \\
\cline { 2 - 3 } & 8 & $\begin{array}{l}\text { Physical activity is severely limited. You can read and } \\
\text { converse with effort. Nausea and dizziness set in as factors of } \\
\text { pain. }\end{array}$ \\
\cline { 2 - 3 } & 9 & $\begin{array}{l}\text { Unable to speak. Crying out or moaning uncontrollably - } \\
\text { near delirium. }\end{array}$ \\
\cline { 2 - 3 } & 10 & Unconscious. Pain makes you pass out. \\
\hline
\end{tabular}

Table 1: Allina Health Pain Assessment Scale

\subsection{Results}

The patient is checked for the different symptom pains by the questionnaire of the Mankoski pain scale. The classification of patients is shown in table 2 at the before of treatment, after the first course and after the last course. 


\begin{tabular}{lcccc}
\hline Level pain & Score & $\begin{array}{l}\text { Before } \\
\text { treatment (B) }\end{array}$ & $\begin{array}{l}\text { After the first } \\
\text { course (A1) }\end{array}$ & $\begin{array}{l}\text { After the last } \\
\text { course (A2) }\end{array}$ \\
\hline No pain & 0 & 0 & 0 & 11 \\
\hline Minor & $1-3$ & 0 & 9 & 10 \\
\hline Moderate & $4-6$ & 6 & 12 & 3 \\
\hline Serve & $7-10$ & 19 & 4 & 1 \\
\hline
\end{tabular}

Table 2: Classify patients according to the Mankoski pain scale

From table 2, before treatment, most patients are immoderate pain level to severe pain. After the doctor and physician referral for treatment with low-level laser, patients agree to treat by our method. They expect positive treatment results before surgical. After the first course, the number of patients at severe pain decreased - only have 4 patients in this case when compared to before treatment (19 cases), the majority of patients feel pain on moderate (12 cases) and minor ( 9 cases). After the last course, only 1 patient feels severe pain, the majority of patients feel minor (10 cases) and 11 patients have no pain.

We used the IBM SPSS statistics 22 software that assesses the reliability of the low-level laser method. We used Paired Samples T-Test Output for each pair (B - A1; B - A2; A1 - A2) with 95\% Confidence Interval of the Difference (table 3).

\begin{tabular}{llrrrr}
\hline & Mean & $\begin{array}{c}\text { Std. } \\
\text { Deviation }\end{array}$ & $\begin{array}{c}\text { Std. Error } \\
\text { Mean }\end{array}$ & \multicolumn{1}{c}{$\begin{array}{l}\text { Sig. (2- } \\
\text { tailed) }\end{array}$} \\
\hline Pair 1 & B - A1 & 3.025 & 1.449 & 0.162 & 0.000 \\
Pair 2 & B - A2 & 5.313 & 1.269 & 0.142 & 0.000 \\
Pair 3 & A1 - A2 & 2.288 & 0.996 & 0.111 & 0.000 \\
\hline \hline
\end{tabular}

Table 3: Paired Samples Test with 95\% Confidence Interval of the Difference

In table 3, 95\% Confidence Interval of the Difference, the value sig. approximately $0(<0.05)$ when we compare each pair. The data correlate with each other. Measurements show that the use of low-level semiconductor lasers therapy for bone regeneration. This method has been highly effective which reduced pain rapidly. These are crucial results that we apply this method to the community.

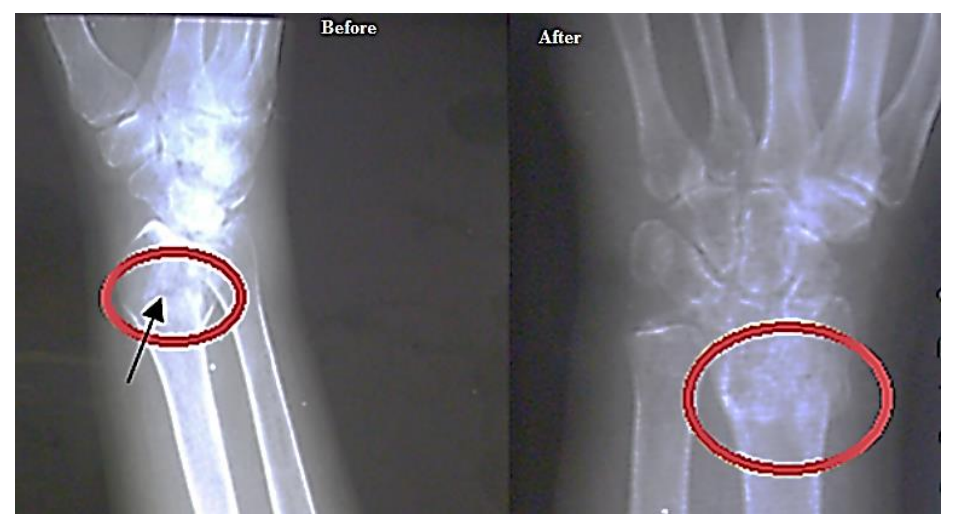

Figure 4: Results before and after treatment of L6 patients ( 82 years old)

Figure 4 is an X-ray picture of the wrist of an 82-year-old patient before and after treatment. Patients with wrist fractures, feeling sharp pain and could not move. After treatment, she no longer felt pain and her hands were able to move. Observing the results of the X-rays, we found that there was no fracture in the wrist bone position. 
Figure 5 shows the results of an X-ray of a 65-year-old patient, the thumb bone of the hand is broken, the finger is swollen, unable to move before and after treatment. After 3 treatments, the broken finger was completely recovered and the hand was flexible again.
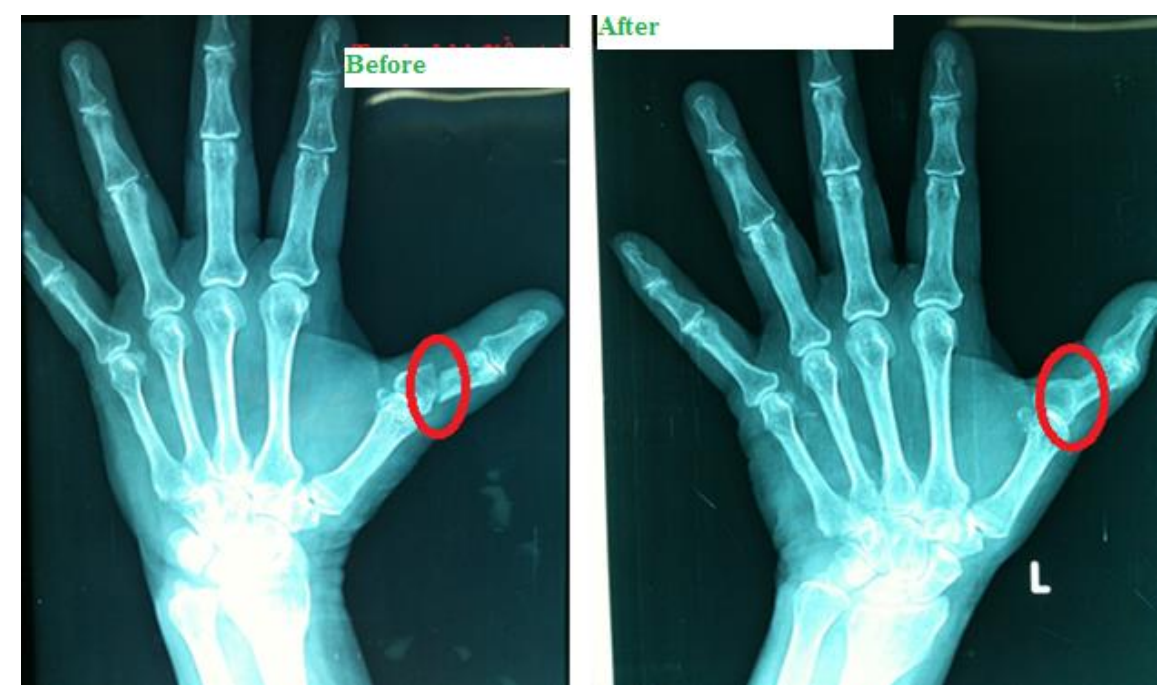

Figure 5: Results before and after 3 courses of treatment of L23 patients (65 years old)

\section{Discussions}

Using low-level laser in continuous mode impact on the position of the mouse fractured tibia effective fast bone healing through biological stimulation on osteoblasts in a short time [2]. Using a laser with the wavelength of $830 \mathrm{~nm}$ with appropriate projection dose on osteoblasts also brings positive effects on the crystalline chemical composition of the bones (from $44.14 \%$ to $54.57 \%$ ), Alkaline Phosphatase activity in osteoblasts increased, mitochondria increased sharply, and the density of osteoblasts increased [3-8]. Several other studies also use low-level lasers (650nm, 670nm, $680 \mathrm{~nm}, 780 \mathrm{~nm}$, etc.) to evaluate the repair of bone defects with the recorded results of inhibiting the inflammatory process, increases bone repair, wound rapid recovery in the short term (21 days or 30 days) [9-18]. Especially, the treatment is carried out on animals with bone defects and diabetes, when using the low-level laser with $808 \mathrm{~nm}$ and $904 \mathrm{~nm}$ wavelengths to evaluate bone healing for diabetic animals; results showed that low-level laser accelerates bone healing. [19, 20].

\section{Conclusions}

From the results of research on dog treatment and clinical treatment of patients, we have recorded no cases of adverse effects on patients' health. The use of the two-wavelength effect in the treatment of fractures indicates that bone formation occurs more rapidly when interacting with a low-level laser on the site of a fractured bone. This is a useful treatment for elderly patients who have a new bone creation process slowly. 


\section{References}

[1] N. T. Vinh and c. sự, Khái luận Y Học Phuc Hồi: Trung Tâm Phục Hồi Chức Năng, Câu Lạc Bộ Y Học Dân Tộc - Sở Y Tế Tp. HCM, 1982.

[2] O. Dörtbudak, R. Haas, and G. Mailath-Pokorny, "Biostimulation of bone marrow cells with a diode soft laser," Clinical Oral Implants Research, vol. 11, pp. 540 - 545, 2000.

[3] R. Hübler, E. Blando, L. Gaião, P. E. Kreisner, L. K. Post, C. B. Xavier, et al., "Effects of low-level laser therapy on bone formed after distraction osteogenesis," Lasers in Medical Science, vol. 25, pp. 213 - 219, 2010.

[4] H. O. S. Filho, A. C. Reimer, C. Marcantonio, E. M. Jr., and R. A. C. Marcantonio, "Effects of low-level laser therapy $(685 \mathrm{~nm})$ at different doses in osteogenic cell cultures," Lasers in Medical Science, vol. 26, pp. 539 - 543, 2011.

[5] A. C. M. Renno, P. A. McDonnell, M. C. Crovace, E. D. Zanotto, and L. Laakso, "Effect of $830 \mathrm{~nm}$ Laser Phototherapy on Osteoblasts Grown In Vitro on Biosilicate Scaffolds," Photomedicine and Laser Surgery, vol. 28, pp. 131 - 133, 2010.

[6] A. R. Coombe, C.-T. G. Ho, M. A. Darendeliler, N. Hunter, J. R. Philips, C. C. Chapple, et al., "The effects of low-level laser irradiation on osteoblastic cells," Clinical Orthodontics and Research, vol. 4, pp. 3 - 14, 2001.

[7] J. S. Diniz, R. A. Nicolau, N. d. M. Ocarina, F. d. C. Magalhães, R. D. d. O. Pereira, and R. Serakides, "Effect of low-power gallium-aluminum-Arsenicum laser therapy $(830 \mathrm{~nm})$ in combination with bisphosphonate treatment on osteopenic bone structure: an experimental animal study," Lasers in Medical Science, vol. 24, pp. 347 - 352, 2009.

[8] R. R. Poppi, A. L. D. Silva, R. S. Nacer, R. P. Vieira, L. V. F. d. Oliveira, N. S. d. F. Júnior, et al., "Evaluation of the osteogenic effect of low-level laser therapy (808 $\mathrm{nm}$ and $660 \mathrm{~nm}$ ) on bone defects induced in the femurs of female rats submitted to ovariectomy," Lasers in Medical Science, vol. 26, pp. 515 - 522, 2011.

[9] A. L. B. Pinheiro, M. E. M. Gerbi, F. d. A. L. Jr., E. A. C. Ponzi, A. M. C. Marques, C. M. Carvalho, et al., "Bone repair following bone grafting hydroxyapatite guided bone regeneration and infra-red laser photobiomodulation: a histological study in a rodent model," Lasers in Medical Science, vol. 24, 2009.

[10] A. S. Denadai, P. d. T. C. d. Carvalho, F. A. d. Reis, A. C. G. Belchior, D. M. Pereira, D. M. Dourado, et al., "Morphometric and histological analysis of low-power laser influence on bone morphogenetic protein in bone defects repair," Lasers in Medical Science, vol. 24, pp. 689 - 695, 2009.

[11] X. Liu, R. Lyon, H. T. Meier, J. Thometz, and S. T. Haworth, "Effect of Lower-Level Laser Therapy on Rabbit Tibial Fracture," Photomedicine and Laser Surgery, vol. 25, pp. 487 494, 2007.

[12] D. A. A. Pires-Oliveira, R. F. O. S. U. Amadei, C. Pacheco-Soares, and R. F. Rocha, "Laser $904 \mathrm{~nm}$ action on bone repair in rats with osteoporosis," Lasers in Medical Science, vol. 21, pp. $2109-2114,2010$.

[13] S. K. Shakouri, J. Soleimanpour, Y. Salekzamani, and M. R. Oskuie, "Effect of low-level laser therapy on the fracture healing process," Lasers in Medical Science, vol. 25, pp. 73 77, 2010.

[14] E. F. Pípi, D. A. Ribeiro, J. U. Ribeiro, P. Bossini, P. Oliveira, N. A. Parizotto, et al., "LowLevel Laser Therapy Induces Differential Expression of Osteogenic Genes During Bone Repair in Rats," Photomedicine and Laser Surgery, vol. 29, pp. 311 - 317, 2011.

[15] L. A. D. S. Merli, M. T. B. R. D. Santos, W. J. Genovese, and F. Faloppa, "Effect of LowIntensity Laser Irradiation on the Process of Bone Repair," Photomedicine and Laser Surgery, vol. 23, pp. 212 - 215, 2005. 
[16] M. A. Matsumoto, R. V. Ferino, G. F. Monteleone, and D. A. Ribeiro, "Low-level laser therapy modulates cyclo-oxygenase-2 expression during bone repair in rats," Lasers in Medical Science, vol. 24, pp. 195 - 201, 2009.

[17] K. T. Atasoy, Y. T. Korkmaz, E. Odachi, and H. Hanci, "The efficacy of low-level $940 \mathrm{~nm}$ laser therapy with different energy intensities on bone healing," Brazilian Oral Research, vol. 31, 2017.

[18] C. R. Tim, K. N. Z. Pinto, B. R. O. Rossi, K. Fernandes, M. A. Matsumoto, N. A. Parizotto, et al., "Low-level laser therapy enhances the expression of osteogenic factors during bone repair in rats," Lasers in Medical Science, vol. 29, pp. 147 - 156, 2014.

[19] H. Mohamed, E. Mohamed, and Z. Mohamed, "low power laser effect on bone healing in the diabetic induced animal model," International Journal of Academic Research vol. 2, pp. 143 - 149, 2010.

[20] U. K. Akyol and Metin Gungormus "Effect of Biostimulation on Healing of Bone Defects in Diabetic Rats," Photomedicine and Laser Surgery, vol. 28, pp. 411 - 416, 2010. 